\title{
The Effect of Apomorphine, MK-212 (6-chloro-2-[1-piperazinyl]-pyrazine) and Placebo on Smooth Pursuit Gain and Corrective Saccades in Normal Subjects
}

Lee Friedman, Ph.D., John A. Jesberger, B.A., and Herbert Y. Meltzer, M.D.

The effects of apomorphine $(0.01 \mathrm{mg} / \mathrm{kg} \mathrm{SC})$ a directacting dopamine (DA) agonist, MK-212 (6-chloro-2-[1piperazinyll-pyrazine) (20 mg PO), a direct-acting serotonin (5-HT) agonist, and placebo on smooth pursuit eye movements were evaluated in 10 to 12 normal volunteers. Smooth pursuit was tested just prior to administration of either apomorphine, MK-212, or placebo (on separate days), and then repeatedly tested at 30 min intervals for two hours after dose administration. The smooth pursuit targets were a series of predictable, constant velocity ramps with velocities of $5 \% / \mathrm{sec}$ (slow target) and $20 \% \mathrm{sec}$ (fast target). Eye movements were recorded with infrared oculography, and the following six measures were obtained; steady-state gain (slow-targetgain; fast-target-gain), corrective catch-up saccade (CUS) rate (slow-target-CUS-rate; fast-target-CUS-rate), and CUS amplitude (slow-target-CUS-amplitude; fast-targetCUS-amplitude). The placebo test yielded a statistically significant monotonic decrease over time in slow-targetgain and corresponding increase in slow-target-CUS-

KEY WORDS: Smooth pursuit; Gain; Serotonin; Dopamine; Apomorphine; MK-212; Normal volunteers

From the Eye Movement Laboratory, Laboratory of Biological Psychiatry, Department of Psychiatry, Case Western Reserve University, Cleveland, $\mathrm{OH}$.

Address reprint requests to Lee Friedman, Ph.D., Department of Pyschiatry, Hanna Pavilion, Room B 68, Case Western Reserve University, Cleveland, $\mathrm{OH} 44106$.

Received January 19, 1993; revised November 15, 1993, Revised March 10, 1994; accepted March 17, 1994. rate, but no effects of placebo were noted for the fast target. Apomorphine injection produced a marked reduction in both slow-target-gain and fast-target-gain at 30 min, returning to baseline thereafter. Apomorphine injection also produced a statistically significant increase in slow-target-CUS-amplitude. Ingestion of MK-212 produced a statistically significant increase in slow-targetgain and fast-target-gain as well as a corresponding decrease in slow-target-CUS-rate and fast-target-CUSrate at $90 \mathrm{~min}$ or $120 \mathrm{~min}$. There was evidence that the decline in slow-target-gain after apomorphine was associated with side-effects such as sleepiness, but the decline in fast-target-gain was not related to side-effects. The improved smooth pursuit performance after MK-212 was not related to side-effects. The data suggest that serotoninergic stimulation can improve smooth pursuit performance, whereas dopaminergic stimulation worsens this performance. [Neuropsychopharmacology 11:4962, 1994]

Although abnormal smooth pursuit eye-tracking is well documented in schizophrenia (Clementz and Sweeney 1990; Abel et al. 1992; Levy et al. 1993), there are few studies addressing the possible neurochemical underpinning of this deficit. Two neurotransmitters that have been implicated in the pathophysiology of schizophrenia are dopamine (DA) and serotonin (5-HT) (Meltzer and Stahl 1976; Meltzer 1989; Davis et al. 1991). Although some studies have attempted to relate eye movement dysfunction to neurochemical mechanisms of schizophrenia (see discussion), few studies have used direct-acting agonists, or addressed the role of $5-\mathrm{HT}$. 
Neuroleptic drugs share in common the ability to block $\mathrm{D}_{2}$ DA receptors at clinically effective doses (Wiesel et al. 1990); thus, any effect produced by this chemically diverse class of drugs might indicate the existence of a tonic direct or indirect $\mathrm{D}_{2} \mathrm{DA}$ receptormediated influence on eye-tracking. The effect of chronic treatment with neuroleptic drugs on eyetracking in patients with schizophrenia has been recently reviewed (Levy et al. 1983; Lipton et al. 1983; Abel and Hertle 1988; Spohn et al. 1988). No effect of typical neuroleptics has been documented. These results indicate that smooth pursuit eye-tracking in patients with schizophrenia is not sensitive to diminished $\mathrm{D}_{2}$ receptor stimulation. This does not eliminate the possibility that smooth pursuit is modulated by dopaminergic stimulation in normal subjects, or that enhanced dopaminergic activity may affect smooth pursuit. To our knowledge there are no published studies of the acute effects of neuroleptics or dopamine agonists on specific quantitative smooth pursuit measures in healthy normal subjects, or schizophrenic patients. ${ }^{1}$ Thus, firm documentation of the absence of an effect of $D_{2}$ DA receptor blockade, or stimulation on smooth pursuit performance is lacking.

Evaluation of the potential role of neurotransmitters in smooth pursuit by administering direct-acting agonists has considerable potential to clarify the regulation of this important function. Apomorphine is a mixed $D_{1}$ and $D_{2}$ direct-acting $D A$ agonist (Schechter and Greer 1987) that can stimulate both DA autoreceptors and postsynaptic receptors (Cooper et al. 1991). Low doses are thought to preferentially stimulate autoreceptors (Meltzer 1981), because these receptors are more sensitive to agonists (Cooper et al. 1991). Autoreceptor stimulation leads to a decrease in DA neuronal firing, synthesis, and release (Meltzer 1982; Goldstein et al. 1990). At higher doses, postsynaptic responses should predominate (Cooper et al. 1991).

The role of 5-HT in smooth pursuit performance can also be addressed with a direct-acting agonist such as MK-212 (6-chloro-2[1-piperazinyl]-pyrazine). This compound is an arylpiperazine that has the behavioral

\footnotetext{
${ }^{1}$ There are two published reports on the acute effects of neuroleptics on eye-tracking performance, but the eye movement analysis methods employed in these two studies were crude and difficult to relate to current fındings. Holzman et al. (1975) reported on the qualitative effects ("normal" versus "deviant" tracking) and quantitative effects ("velocity arrests") of acute administration of chlorpromazine ( 0.67 or $1.33 \mathrm{mg} / \mathrm{kg}$ p.o.) on electro-oculogram (EOG) recordings of pendulum tracking, and noted no deviant recordings, and no increase in velocity arrests resulting from drug administration. Ando et al. (1986) reported that haloperidol, in a range of doses starting from $0.004-0.032 \mathrm{mg} / \mathrm{kg}$ (i.m.) produced ". . . disruptions in smooth pursuit (that) were characterized by eye fixation accompanied by some saccadic movements" (pp 697-698).
}

and chemical effects of a direct-acting 5-HT agonist (Clineschmidt et al. 1977; Clineschmidt 1979). Most of the evidence suggests that MK-212 acts via the $5-\mathrm{HT}_{2 \mathrm{~A}}$ and $5-\mathrm{HT}_{2 \mathrm{C}}$ receptors, but there is evidence linking MK-212 to $5-\mathrm{HT}_{1 \mathrm{~A}}$ and $5-\mathrm{HT}_{2 \mathrm{~B}}$ receptors. It has affinity for $5-\mathrm{HT}_{1 \mathrm{~A}}, 5-\mathrm{HT}_{2 \mathrm{~A}}$, and $5-\mathrm{HT}_{2} \mathrm{C}$ binding sites (Hoyer 1988; Roth et al. 1992); however, MK-212 has 25-fold greater affinity for the clonal $5-\mathrm{HT}_{2 \mathrm{C}}$ than the $5-\mathrm{HT}_{2 \mathrm{~A}}$ receptor (Roth et al. 1992; Choudhary et al. 1993). Also, some endocrine effects of MK-212 in rodents have been suggested to be mediated by $5-\mathrm{HT}_{2} \mathrm{C}$ receptor stimulation (King et al. 1989). Furthermore, some effects of MK212 (e.g., reinforcement of fixed interval responding, are blocked by ketanserin, a 5- $\mathrm{HT}_{2 \mathrm{~A} / 2 \mathrm{C}}$ antagonist) (Mansbach and Barrett 1986). However, there is evidence that MK-212 may interact with the 5- $\mathrm{HT}_{1 \mathrm{~A}}$ receptor. Thus, MK-212 markedly inhibits the firing of raphe neurons (Yarbrough et al. 1984), an effect it shares with $5-\mathrm{HT}_{1 \mathrm{~A}}$ agonists. The effects of MK-212 in man may be mediated by stimulation of $5-\mathrm{HT}_{1 \mathrm{~A}}, 5-\mathrm{HT}_{2 \mathrm{~A}}$, or $5-\mathrm{HT}_{2} \mathrm{C}$ receptors. Thus, the prolactin-stimulating effects of $\mathrm{MK}$ 212 in man are blocked by pindolol, a beta-adrenergic antagonist with selective $5-\mathrm{HT}_{1 \mathrm{~A}}$ antagonist activity (Meltzer et al., unpublished data) and are also blocked by clozapine, a $5-\mathrm{HT}_{2 \mathrm{~A}} / 5-\mathrm{HT}_{2 \mathrm{C}}$ antagonist (Roth et al. 1992). Finally, the $5-\mathrm{HT}_{2 \mathrm{~B}}$ receptor is implicated by a study demonstrating that MK-212 causes a dose-dependent contraction of rat fundus strips (Clineschmidt et al. 1985).

A proper evaluation of the neurotransmitter regulation of smooth pursuit also requires a sophisticated analysis of smooth pursuit performance. Because the function of the smooth pursuit system is to match eyevelocity to target-velocity, the ratio of eye-velocity to target-velocity, (i.e. gain), is the key smooth pursuit measure. Perfect performance yields a gain of 1.0, whereas subjects who track more slowly than the target have gains less than 1.0. Gain is inversely related to target velocity and generally increases with target predictability (Levin et al. 1988). When gain is less than 1.0 , position error accumulates, because the eye falls behind the target. This position error is typically corrected with a small CUS in the direction of the target. The nonlinear relationship between gain, CUS amplitude, and CUS rate has been modeled by Friedman et al. (1991). ${ }^{2}$

The purpose of the present study was to test the effect of apomorphine and MK-212 on smooth pursuit gain, CUS rate, and CUS amplitude in normal volunteers.

\footnotetext{
${ }^{2}$ The relationship is described by the equation $G=1-\left((A R) / V_{t}\right)$, where $G=$ gain, $A=C U S$ amplitude, $R=C U S$ rate and $V_{t}=$ target velocity.
} 


\section{MATERIALS AND METHODS}

\section{Subjects}

Twelve normal volunteers (10 male and two female) were recruited by advertisement. They underwent a physical and neurological examination, as well as a number of standard laboratory tests to screen for medical illness. Also, subjects with a past psychiatric history or a psychiatric history in first-degree relatives were excluded. The subjects were not taking any psychoactive medications at the time of the study, and had been free of all medication for at least one week before the study. The mean age was 27.5 years \pm 5.9 years SD. All subjects provided informed consent.

\section{Experimental Procedure}

All subjects underwent all drug conditions (placebo, apomorphine, MK-212). Each drug was administered on a separate day, with a minimum of 48 hours between studies. For each test day, the subjects fasted from 12:00 A.M. and through the morning study. They reported to the eye-tracking laboratory at 9:00 A.M. The baseline eye-tracking recording was initiated after completion of visual acuity and ocular dominance tests, and a series of questions regarding the subject's ophthalmologic history. The subjects then received one of the following: (1) an injection of apomorphine $(0.01 \mathrm{mg} / \mathrm{kg} \mathrm{SC})$ and a placebo tablet, (2) a placebo injection and a tablet of MK-212 (20 mg), or (3) a placebo injection and a placebo tablet. The drug to be given on a particular day was chosen randomly until each subject had been tested three times, once under each of the three drug conditions. Both the subject and the eye-tracking personnel were blind to the drug administered on a given day. The eye-tracking test was repeated every $30 \mathrm{~min}$ for $2 \mathrm{hrs}$.

\section{Pharmacokinetics}

The pharmacokinetics of apomorphine (bolus SC injection) in humans have been described by Gancher et al. (1989). According to them, apomorphine is rapidly absorbed following subcutaneous injection, with peak plasma concentrations occurring 3 min following administration. Apomorphine rapidly equilibrates between blood and brain due to its high lipid solubility. Concentrations are up to eight times higher in brain than plasma. Antiparkinsonian effects of apomorphine are observed within $7 \mathrm{~min}$ and last for up to $1 \mathrm{hr}$ following injection (Gancher et al. 1989; Truelle et al. 1975).

Peak plasma levels were noted 2 hours after a single oral dose of MK-212 in man (Merck Sharpe and Dohme Pharmaceuticals Inc., personal communication). No pharmacokinetic studies or detailed metabolic studies of MK-212 in man have been published; how- ever, the time course of central effects of MK-212 have been reported. The stimulating effects of MK-212 on serum cortisol and prolactin peaked between $90 \mathrm{~min}$ and 120 min (Lowy and Meltzer 1988). The temperature elevating effects of MK-212 peaked at $118 \mathrm{~min}$ (Lee et al. 1992).

\section{Smooth Pursuit Stimulus}

For ten of the twelve subjects, the tracking target was a red $\mathrm{He} / \mathrm{Ne}$ laser reflected off a computer-controlled mirror galvanometer, and projected on a 5 - $\mathrm{ft}$ radius arc located 5-ft from the eyelid of the subject's dominant eye. Subjects were seated and the head was held firmly in place in a headrest by chin and forehead straps. The galvanometer received its input from an amplifiercontroller unit. The input to the galvanometer controller was an analog signal generated by a D/A converter in an IBM PC-type computer. The first target waveform was a set of 10 constant velocity $\left(5^{\circ} / \mathrm{sec}\right)$ horizontal ramps (five ramps to the left and five to the right) with an excursion of $\pm 15^{\circ}$. There was a 2.5 second pause between each ramp. The second waveform presented was identical to the first, except for velocity that was $20 \% \mathrm{sec}$. For the first two subjects (subjects GU and MP), the target was a bright spot on a monitor, and only a $5^{\circ} / \mathrm{sec}$ velocity with $\pm 10^{\circ}$ excursion was presented, as described by Friedman et al. (1991). The monitor and laser stimuli were identical in all remaining respects.

As described previously, two subjects were not tested at the $20 \% \mathrm{sec}$ target speed. An additional subject failed to complete the $20 \%$ sec recording session under the apomorphine condition. Thus $n=12$ for all conditions at $5 \% / \mathrm{sec}, n=10$ for placebo and MK-212 conditions at $20 \% \mathrm{sec}$, and $n=9$ for the apomorphine condition at $20 \% \mathrm{sec}$.

\section{Eye Movement Recording}

The recording and analysis methods have been described in detail (Friedman et al. 1991; Friedman et al. 1992a; Friedman et al., 1992b). In brief, eye movements were recorded monocularly from the dominant eye with infrared oculography. The signal conditioning unit was operated in the filter-out position. The output was led to a $50-\mathrm{Hz}$ notch filter and 5-pole Butterworth low pass filter at $125 \mathrm{~Hz}(3 \mathrm{~dB})$. Target and eye position signals were digitally sampled at 400 samples per sec per channel (12 bit resolution) and stored on disk for offline analysis. Eye-velocity was obtained digitally, using the computational method of Usui and Amidror (1982) with parameters $\mathrm{n}=1.5, \mathrm{~L}=0.5$ (bandwidth $\mathrm{DC}-52.5 \mathrm{~Hz}$ ).

\section{Eye Movement Analysis}

All eye movement records were scored blind to drug condition. 
To prevent the possible contamination of our pursuit measures by blinks, these events were marked interactively. Eye movement data from $150 \mathrm{msec}$ before to $500 \mathrm{msec}$ after each blink were omitted from the analysis. With infrared oculography, blinks appear as sharp, fast, bipolar waves or spikes.

Smooth pursuit recordings typically consist of straight-line segments interrupted by saccades. The start and end of these straight line smooth pursuit segments, between saccades, were marked interactively. To compute segment gain, a regression line (least squares) for the eye position data was computed, and the slope of this line was divided by the slope of the target position trace. The average gain was computed after removal of segments with pursuit gain with outlying or extreme gain values. Outliers were 1.5 times the interquartile range above the 75 th percentile or below the 25th percentile (Norusis 1988). Gain averaged over time was calculated for each subject. For this, the sum of the product of gain and duration for each segment was divided by the summed durations of all segments (Friedman et al. 1991). The interrater reliability of this method of scoring gain, as assessed by the intraclass correlation coefficient, was 0.89 (Friedman et al. 1992b).

The detection and measurement of corrective catchup saccade (CUS) was a multi-step process. Because by definition, saccades cannot occur during pursuit segments, the interval between consecutive segments was displayed, and the operator indicated if a CUS occurred. Because CUS compensate for the position error that accumulates during smooth pursuit, a CUS must have been preceded and followed by segments during which the subject was near the target, and the gain was clearly greater than 0. CUS must always be in the direction of target movement. After CUS detection, the beginning and ending points of a CUS were determined automatically according to the following algorithm: (1) scan the intersegment interval for the point of peak velocity; (2) find the starting point by moving backwards in time from the point of peak velocity to the first point at which the eye velocity was at or below the target velocity; and, (3) find the ending point by moving forward in time from the point of peak velocity to the furst point at which the eye velocity was at or below target velocity. The difference between eye position at these two points was taken as a measure of saccade amplitude in degrees of visual angle. The number of CUS was divided by the tracking time to yield a measure of rate (CUS / sec).

\section{Subjective Ratings of Side-Effects}

Subjective ratings of side-effects were made after each eye movement measurement. The Stanford Sleepiness Scale (Hoddes et al. 1973) was used to assess sleepiness. It is a seven-point scale with descriptive anchors.
Increasing scores are associated with increasing feelings of sleepiness. In addition, nausea, dizziness, restlessness, strangeness, and irritability were also rated with 11 point scales, with 0 indicating "not at all," and 10 indicating "very much."

\section{Statistical Analysis}

Nonparametric statistical tests were employed throughout, because much of the data was nonnormally distributed. Also, these tests are generally more conservative, and may be more appropriate with modest sample sizes. For each drug (placebo, apomorphine, MK-212), the drug effect was first tested with a Friedman Two-Way ANOVA by Ranks (Friedman test). This test can be thought of as a nonparametric repeatedmeasures ANOVA (Siegel and Castellan 1988). The test statistic is denoted $F_{r}$. Following a significant $F_{r}$, posthoc comparisons between any postdrug time point (T30-T120) and the predrug baseline (T0) were performed using a procedure that controlled for such multiple, nonindependent comparisons (Siegel and Castellan 1988). In several cases, the time response appeared to be either a monotonic increase or decrease. In such cases, the monotonic trend was tested with the nonparametric Page Test for Ordered Alternatives ("Page Test") (Siegal and Castellan 1988). To assess the strength of association or effect size of a significant result, $\eta^{2}$ (eta-squared) was computed with parametric techniques (Tabachnick and Fidell 1989). This measure can be conceptualized as the proportion of the variance in a dependent variable that is accounted for by a particular effect. As a further check on the result, Wilcoxon Signed Rank Tests were computed comparing ondrug data to placebo data for each time point for each smooth pursuit measure.

The effect of the drugs or placebo on side-effects was tested with a Wilcoxon Signed Rank Test. Correlation analyses employed Spearman rank-order correlation coefficients $\left(r_{s}\right)$. All $p$-values are two-tailed.

\section{RESULTS}

\section{The Effects of Placebo on Smooth Pursuit Measures}

The Friedman tests of the effect of placebo on the six smooth pursuit measures were all nonsignificant (Figures $1 \mathrm{a}, 1 \mathrm{~d}, 2 \mathrm{a}, 2 \mathrm{~d}, 3 \mathrm{a}$, and $3 \mathrm{~d}$ ). However, there was a statistically significant monotonic decrease in slowtarget-gain (Page test $p<.05$, Figure $1 \mathrm{a}, \eta^{2}$ for the linear trend $=0.28$ ) and a statistically significant monotonic increase in slow-target-CUS-rate (Page test $p<.05$, Figure $2 a, \eta^{2}$ for the linear trend $=0.23$ ).

Individual slow-target-gain scores for each subject at baseline and at the time of peak effect of placebo (T120) are listed in Table 1. Two hours after placebo, 


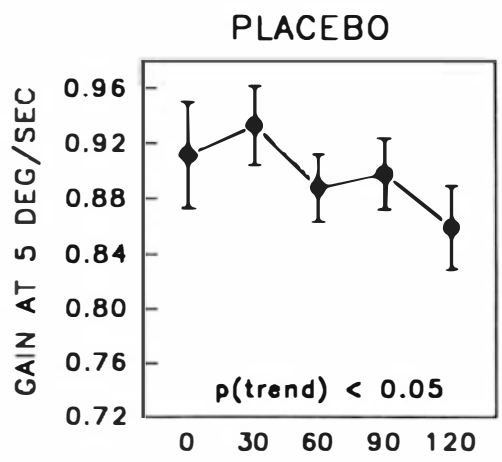

a) TIME ( $\mathrm{min}$ )

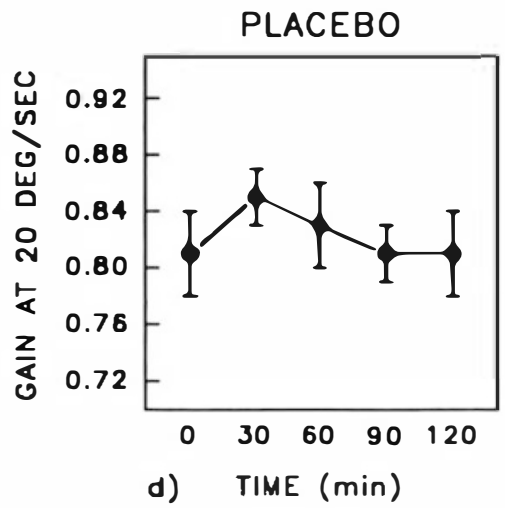

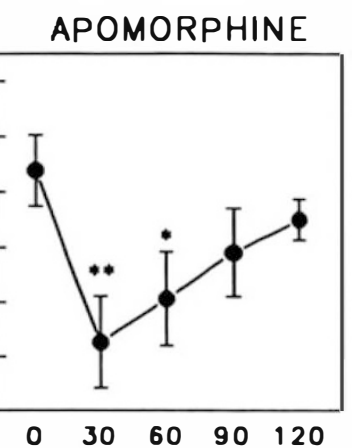

b) TIME ( $\mathrm{min}$ )

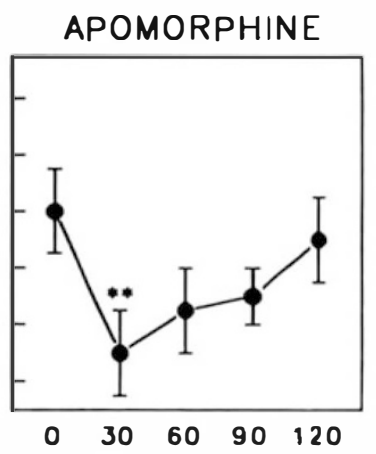

e) TIME ( $\mathrm{min})$

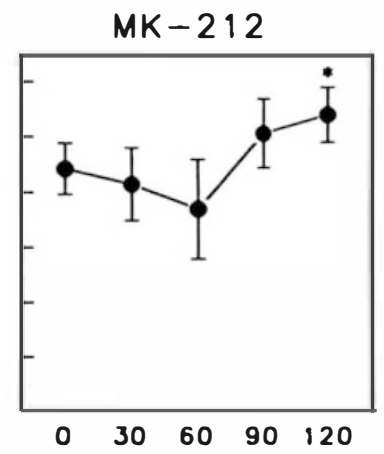

c) TIME ( $\mathrm{min})$

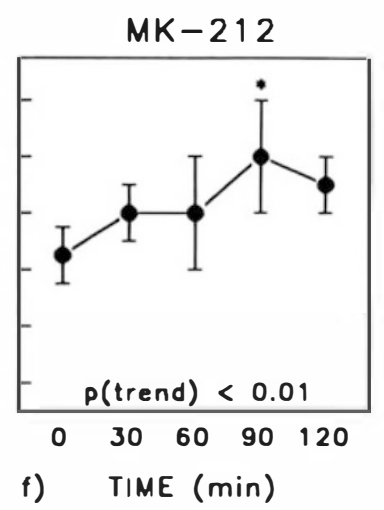

Figure 1. Effect of placebo, apomorphine or MK-212 on smooth pursuit gain. The data are plotted as mean \pm standard error of the mean. Drugs or placebo were given after T0. (a) For placebo at $5 \% / \mathrm{sec}$, there was a statistically significant monotonic decrease in gain over time $(p<.05)$, but there were no significant differences between any time points. (b) For apomorphine at $5 \% \mathrm{sec}$, note the sharp decline in gain $30 \mathrm{~min}$ after injection. Gain was significantly reduced at T30 ("** $p<.01)$ and T60 ( $\left.{ }^{*} p<.05\right)$ compared to baseline (T0). (c) After MK-212, gain was significantly elevated above baseline (T0) at T120 ( $\left.{ }^{*} p<.05\right)$. (d) For placebo at $20 \% \mathrm{sec}$, there was a small initial rise in gain followed by an even more gradual decrease, but no significant differences between any time points was found. (e) For apomorphine at $20 \% \mathrm{sec}$, note the same sharp decline in gain at $30 \mathrm{~min}$ post-injection. As with the slower target, gain was significantly reduced at T30 compared to baseline ("* $p<.01)$. (f) For MK-212 at $20 \% \mathrm{sec}$, there was a statistically significant monotonic increase in gain $(p<.01)$. The peak gain at T90 was significantly higher $\left({ }^{*} p<.05\right)$ than at baseline (T0).

slow-target-gain was reduced in eight of the twelve subjects.

\section{The Effects of Apomorphine on Smooth Pursuit Measures}

Apomorphine injection was followed by statistically significant decreases in both slow-target-gain $\left(\mathrm{F}_{\mathrm{r}}=\right.$ 14.68, $p=.005$, Figure $1 \mathrm{~b})$ and fast-target-gain $\left(\mathrm{F}_{\mathrm{r}}=\right.$ $17.60, p=.002$, Figure 1e), as well as a statistically significant increase in slow-target-CUS-amplitude $\left(\mathrm{F}_{\mathrm{r}}=\right.$ $12.78, p=.01$, Figure $3 b$ ). These effects of apomorphine were statistically significant at $30 \mathrm{~min}$ postinjection (all $p<.01, \eta^{2}$ for the decrease in slow-target-gain $=0.74$, $\eta^{2}$ for the decrease in fast-target-gain $=0.64, \eta^{2}$ for the increase in slow-target-CUS-amplitude $=0.47$ ), and one effect (the decrease in slow-target-gain) was still significant at $60 \mathrm{~min}$ postinjection $(p<.05)$. Thereafter, smooth pursuit performance gradually returned to baseline (predrug) levels. Although apomorphine appeared to cause a marked increase in slow-target-CUSrate and fast-target-CUS-rate (Figures $2 \mathrm{~b}$ and $2 \mathrm{e}$ ), there changes were only trends ( $p=.08,0.11$, respectively).

Individual gain scores for each subject at baseline and at the time of peak effect for apomorphine (T30 for both speeds) are listed in Table 1. After apomorphine, slow-target-gain declined in all twelve subjects, and fast-target-gain declined in eight of nine subjects.

\section{The Effects of MK-212 on Smooth Pursuit Measures}

MK-212 ingestion was followed by statistically significant increases in both slow-target-gain $\left(\mathrm{F}_{\mathrm{r}}=11.07, p=\right.$ .03 , Figure $1 c)$ and fast-target-gain $\left(F_{\mathrm{r}}=9.84, p=.043\right.$, Figure 1f), as well as a statistically significant decrease in fast-target-CUS-rate $\left(\mathrm{F}_{\mathrm{r}}=14.00, p=.007\right.$, Figure 2f). The effect of MK-212 ingestion was delayed compared to apomorphine injection, occurring either at 90 

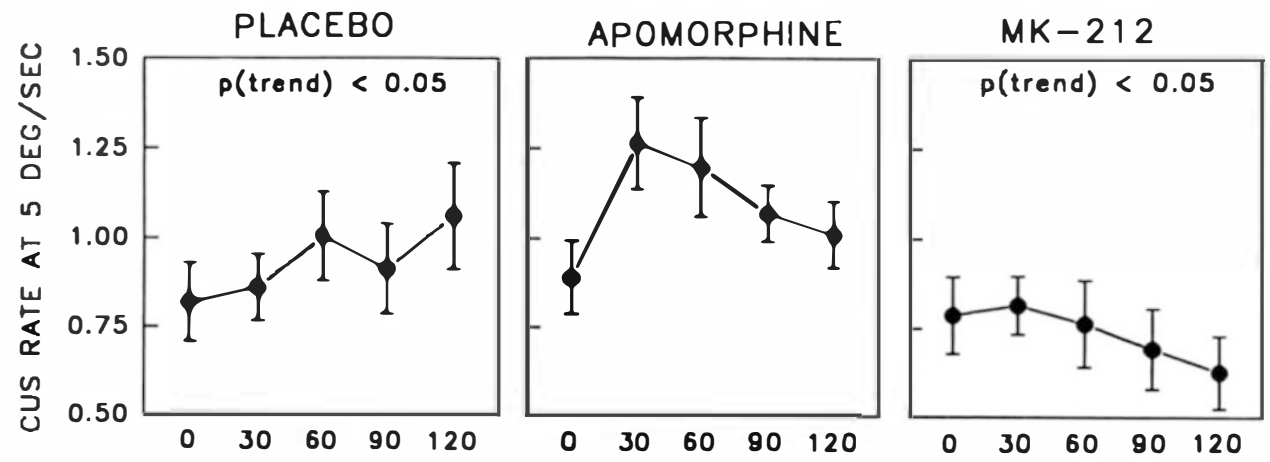

a) TIME (min)

b) TIME ( $\mathrm{min}$ )

c) TIME (min)
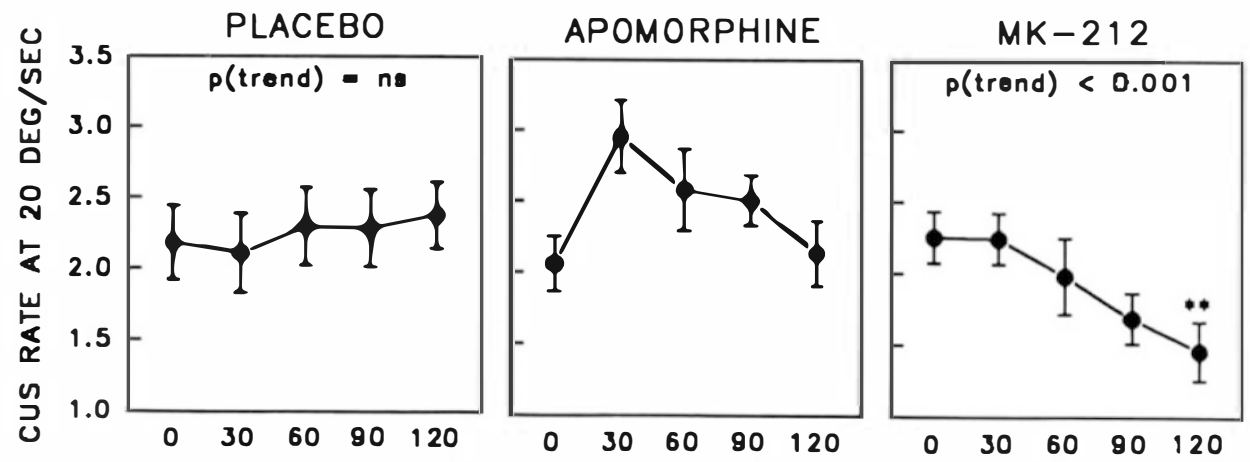

d) TIME (min)

e) TIME (min)

f) TIME (min)

Figure 2. Effect of placebo, apomorphine, or MK-212 on CUS rate. The data are plotted as mean \pm standard error of the mean. Drugs or placebo were given after T0. (a) For placebo at $5^{\circ} / \mathrm{sec}$, there was a statistically significant monotonic increase in CUS rate over time $(p<.05)$, but there were no significant differences between any time points. (b) For apomorphine at $5 \%$ sec, there was an increase in mean CUS rate $30 \mathrm{~min}$ after injection, but it was not statistically significant. (c) After MK-212, there was a statistically significant monotonic decrease in CUS rate $(p<.05)$. (d) For placebo at $20^{\circ} / \mathrm{sec}$, there was a weak non significant trent toward increasing CUS rate, and no significant differences between any time points were found. (e) for apomorphine at $20 \% \mathrm{sec}$, the mean increase in CUS rate 30 min post injection was not statistically significant. (f) For MK-212 at $20 \% \mathrm{sec}$, there was a highly significant monotonic decrease in CUS rate $(p<.001)$. The T120 time point was significantly lower than baseline $(p<.01)$.

(Figure 1f) or $120 \mathrm{~min}$ (Figures 1c and 2f) postingestion. Page tests revealed a statistically significant monotonic increase in fast-target-gain $\left(p<.01, \eta^{2}=0.38\right.$, Figure 1f) as well as statistically significant decreases in slowtarget-CUS-rate $\left(p<.05, \eta^{2}\right.$

target-CUS-rate $\left(p<.001, \eta^{2}=0.80\right.$, Figure 2f). MK212 did not significantly affect CUS amplitude (Figures $2 \mathrm{~b}$ and $2 \mathrm{e}$ ).

Individual gain scores for each subject at baseline and at the time of peak effect for MK-212 (T120 for the slow target, T90 for the fast target) are listed in Table 1. After MK-212, gain increased in ten of twelve subjects at $5 \% \mathrm{sec}$, and in eight of ten subjects at $20 \% \mathrm{sec}$.

\section{Drug versus Placebo Comparisons}

Table 2 lists the significance values for a series of Wilcoxon Signed Rank tests comparing apomorphine or MK-212 with placebo at each time point. These results essentially confurm the findings of the within-drug com- parisons described above. Apomorphine was associated with an early, marked reduction in gain, and an increase in CUS rate, and amplitude at both target speeds. MK212 was associated with an increase in slow-target-gain, and a decrease in slow-target-CUS-rate and fast-targetCUS-rate at T120.

\section{Correlations between Drug-Induced Changes in Gain and Baseline Gain}

The decline (T120-T0) in slow-target-gain after placebo at time of peak effect (T120) was correlated with the baseline slow-target-gain $\left(r_{s}=-0.66, p=.02\right)$. The preapomorphine baseline gain was not correlated with the change in gain at T30 (the time of peak effect) after apomorphine at either target speed. Similarly, there was no correlation between pre-MK-212 baseline gain and the peak change in gain after MK-212 (T120) ${ }^{3}$ at either target speed. 


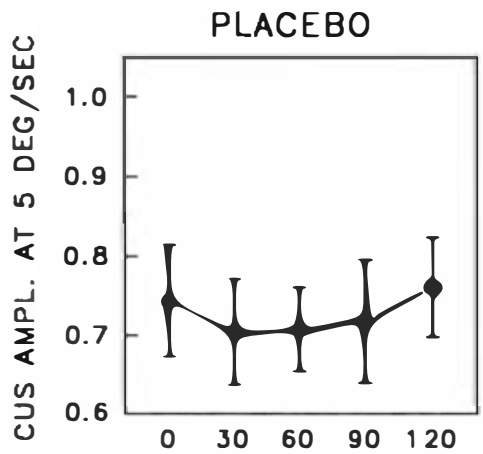

a) TIME (min)

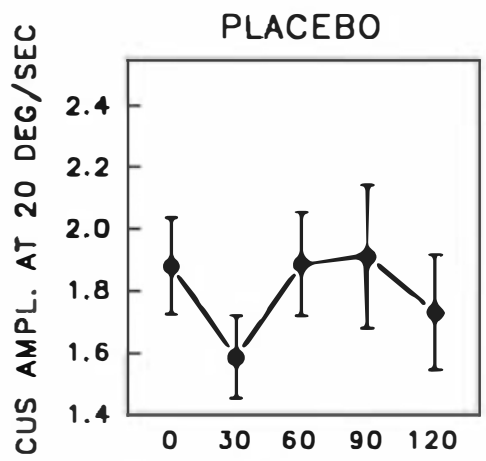

d) TIME (min)

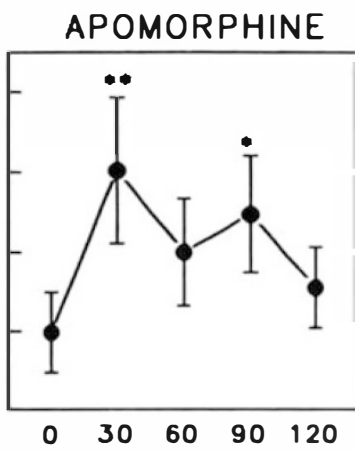

b) TIME (min)

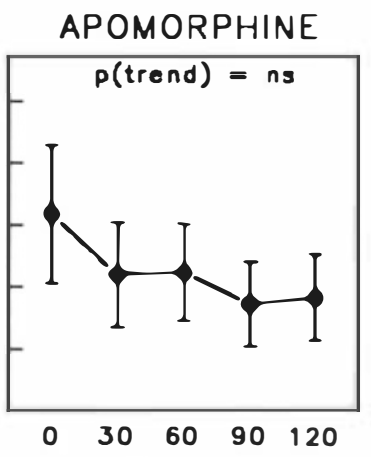

e) TIME (min)

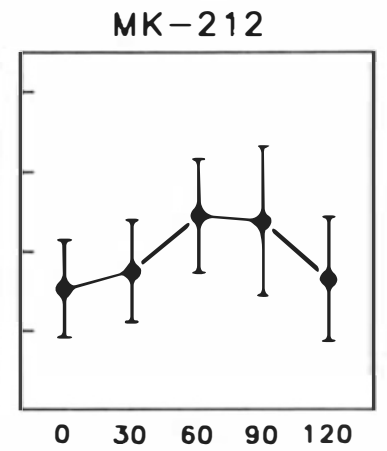

c) TIME ( $\mathrm{min}$ )

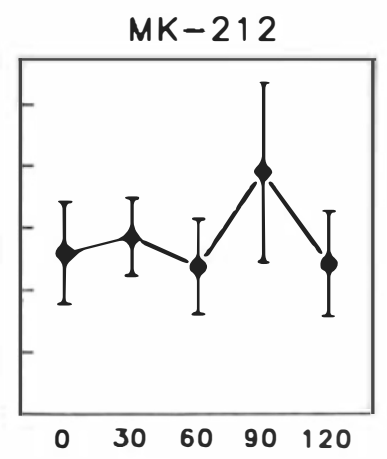

f) TIME (min)

Figure 3. Effect of placebo, apomorphine, or MK-212 on CUS amplitude. The data are plotted as mean \pm standard error of the mean. Drugs or placebo were given after T0. Significant effects occurred only for apomorphine at $5 \% / s e c(b)$. In this case, CUS amplitude was significantly elevated at T30 $(p<.01)$ and T90 $(p<.05)$.

\section{Correlations between Apomorphine-Induced Changes in Gain and MK-212-Induced Changes in Gain}

The effect of apomorphine on slow-target-gain at T30 and the effect of MK-212 on slow-target-gain at T120 were correlated as follows: at the slower target speed, the larger the effect (T30-T0) of apomorphine for a particular subject, the smaller the effect (T120-T0) of MK212 for the same subject $\left(r_{s}=0.67, p=.017\right)$. This relationship was not observed for fast-target-gain $\left(r_{s}=\right.$ $-0.28, p=.46)$.

The effect size for apomorphine or MK-212 for subjects GU and MP were intermediate and completely consistent with the group effects (Table 1).

\section{The Effects of Placebo, Apomorphine or MK-212 on Subjective Ratings of Side-Effects}

The effects of placebo, apomorphine, or MK-212 on side-effects were tested at the time of peak effect for eye movement measures ( $\mathrm{T} 120^{3}$ for placebo and MK-

\footnotetext{
${ }^{3}$ The time of peak effect of MK-212 on slow-target-gain was T120 whereas the time of peak effect on fast-target-gain was T90. To minimize the number of tests performed, T120 was chosen to evaluate the effect of MK-212 on side-effects. This is supported also by the evidence of a monotonic increase in gain over the entire $120 \mathrm{~min}$ period.
}

212, and T30 for apomorphine) (Table 3). The Stanford Sleepiness Scale score was the most sensitive of all subjective ratings to the effects of the drugs, or placebo. Thus, at the time of peak effect of placebo and apomorphine, subjects were significantly more sleepy (Table $3)$. Also, at the time of peak effect of MK-212 there was a trend toward increased sleepiness (Table 3). None of the other side-effect tests (nausea, dizziness, irritability, strangeness) were statistically significant (Table 3 ).

\section{Correlations between Changes in Smooth Pursuit Gain and Changes in Subjective Ratings of Side-Effects}

Correlations were computed relating changes in sideeffect measures with change in gain at the time of peak effect (T120 for slow-target-gain after placebo, T30 for slow-target-gain and fast-target-gain after apomorphine, T120 for slow-target-gain, and T90 for fast-targetgain after MK-212) (Table 4). Side-effect data were analyzed only for subjects with complete side-effect data $(n=9)$. After placebo or MK-212, there were no significant correlations between change in smooth pursuit gain at either target speed and change in subjective ratings of any side-effect. After apomorphine, change in slow-target-gain was significantly inversely correlated with change in sleepiness, dizziness, and irritability at T30 (sleepiness: $r_{s}=-0.84, p=.005$; diz- 
Table 1. Effect of Placebo, Apomorphine, or MK-212 on Gain for Each Subject at Time of Maximum Effect, Sorted by Increasing Effect Size

\begin{tabular}{lccc}
\hline & Placebo \\
& 5\%/sec & \\
\hline Subject & T0 & T120 & Change \\
\hline FE & 0.817 & 0.915 & +0.098 \\
MK & 0.756 & 0.851 & +0.095 \\
WH & 0.867 & 0.935 & +0.068 \\
GU & 0.664 & 0.727 & +0.063 \\
DI & 0.914 & 0.867 & -0.047 \\
AL & 0.934 & 0.874 & -0.060 \\
BR & 0.944 & 0.856 & -0.088 \\
CB & 1.049 & 0.954 & -0.095 \\
JB & 1.130 & 1.024 & -0.106 \\
DA & 0.969 & 0.841 & -0.128 \\
PE & 1.054 & 0.847 & -0.207 \\
YE & 0.841 & 0.621 &
\end{tabular}

Apomorphine

\begin{tabular}{|c|c|c|c|c|c|c|c|}
\hline \multicolumn{4}{|c|}{$5^{\circ} / \mathrm{sec}$} & \multicolumn{4}{|c|}{$20 \% / \mathrm{sec}$} \\
\hline Subject & T0 & T30 & Change & Subject & T0 & T30 & Change \\
\hline DI & 0.825 & 0.800 & -0.025 & CB & 0.838 & 0.851 & +0.013 \\
\hline PE & 1.023 & 0.967 & -0.056 & DI & 0.644 & 0.633 & -0.011 \\
\hline YE & 0.834 & 0.771 & -0.063 & BR & 0.915 & 0.869 & -0.046 \\
\hline $\mathrm{CB}$ & 0.983 & 0.910 & -0.073 & $\mathrm{FE}$ & 0.761 & 0.692 & -0.069 \\
\hline $\mathrm{JB}$ & 0.962 & 0.871 & -0.091 & $\mathrm{JB}$ & 0.809 & 0.695 & -0.114 \\
\hline MP & 0.824 & 0.726 & -0.098 & YE & 0.856 & 0.721 & -0.135 \\
\hline WH & 0.864 & 0.763 & -0.101 & PE & 0.917 & 0.760 & -0.157 \\
\hline $\mathrm{FE}$ & 0.940 & 0.792 & -0.148 & $\mathrm{WH}$ & 0.933 & 0.760 & -0.173 \\
\hline GU & 0.707 & 0.551 & -0.156 & $\mathrm{AL}$ & 0.904 & 0.658 & -0.246 \\
\hline BR & 0.939 & 0.779 & -0.160 & & & & \\
\hline AL & 0.956 & 0.714 & -0.242 & & & & \\
\hline $\mathrm{DA}$ & 0.888 & 0.602 & -0.286 & & & & \\
\hline
\end{tabular}

MK-212

\begin{tabular}{|c|c|c|c|c|c|c|c|}
\hline \multicolumn{4}{|c|}{$5^{\circ} / \mathrm{sec}$} & \multicolumn{4}{|c|}{$20^{\circ} / \mathrm{sec}$} \\
\hline Subject & T0 & T120 & Change & Subject & T0 & T90 & Change \\
\hline DA & 0.933 & 0.876 & -0.057 & DA & 0.850 & 0.694 & -0.156 \\
\hline$A L$ & 0.921 & 0.891 & -0.030 & JB & 0.826 & 0.728 & -0.098 \\
\hline $\mathrm{BR}$ & 1.004 & 1.013 & +0.009 & $\mathrm{CB}$ & 0.905 & 0.939 & -0.034 \\
\hline PE & 0.956 & 0.966 & +0.010 & $\mathrm{FE}$ & 0.796 & 0.847 & +0.051 \\
\hline JB & 0.834 & 0.848 & +0.014 & $\mathrm{AL}$ & 0.725 & 0.786 & +0.061 \\
\hline $\mathrm{MP}$ & 0.847 & 0.873 & +0.026 & PE & 0.891 & 0.959 & +0.068 \\
\hline WH & 0.895 & 0.952 & +0.057 & BR & 0.870 & 0.950 & +0.080 \\
\hline GU & 0.766 & 0.839 & +0.073 & DI & 0.720 & 0.857 & +0.137 \\
\hline $\mathrm{FE}$ & 0.896 & 0.978 & +0.082 & YE & 0.699 & 0.884 & +0.185 \\
\hline CB & 0.934 & 1.029 & +0.095 & WH & 0.855 & 1.161 & +0.306 \\
\hline YE & 0.851 & 0.946 & +0.095 & & & & \\
\hline DI & 0.924 & 1.024 & +0.100 & & & & \\
\hline
\end{tabular}

ziness: $r_{s}=-0.86, p=.003$; irritability: $r_{s}=-0.76$, $p=.018)$, but no correlations were significant for fasttarget-gain ( $p$-values range from .226 to .743).

\section{DISCUSSION}

The major findings of the present study were: (a) that slow-target-gain gradually declined over a 2 hour period after placebo; (b) that slow-target-gain and fast-targetgain declined sharply $30 \mathrm{~min}$ after apomorphine injection; (c) that slow-target-gain at 90 min and fast-targetgain at 120 min were increased after MK-212; and (d) that the effects of apomorphine and MK-212 on slowtarget-gain were inversely correlated. In general, these changes in gain were accompanied by compensating changes in corrective, CUS rate (placebo and MK-212), 
Table 2. Significance $(p)$ Values (Two-Tailed) for Wilcoxon Signed Rank Tests Comparing On-Drug with Placebo

\begin{tabular}{|c|c|c|c|c|c|}
\hline \multicolumn{3}{|c|}{ Apomorphine } & \multicolumn{3}{|c|}{ MK212 } \\
\hline \multicolumn{3}{|c|}{ Slow-Target-Gain } & \multicolumn{3}{|c|}{ Slow-Target-Gain } \\
\hline Time & $\begin{array}{l}\text { Direction of } \\
\text { Drug Effect }\end{array}$ & $p$-Value & Time & $\begin{array}{l}\text { Direction of } \\
\text { Drug Effect }\end{array}$ & $p$-Value \\
\hline T0 & & 0.433 & T0 & & 0.938 \\
\hline T30 & $\downarrow$ & $0.002^{*}$ & T30 & & 0.182 \\
\hline T60 & $\downarrow$ & $0.023^{*}$ & T60 & & 0.875 \\
\hline T90 & & 0.060 & T90 & & 0.182 \\
\hline T120 & & 0.906 & $\mathrm{~T} 120$ & $\uparrow$ & $0.028^{\star}$ \\
\hline
\end{tabular}

\begin{tabular}{lcl}
\multicolumn{3}{c}{ Slow-Target-CUS-Rate } \\
\hline T0 & $\uparrow$ & 0.308 \\
T30 & $\uparrow$ & $0.012^{*}$ \\
T60 & & 0.347 \\
T90 & & 0.272 \\
T120 & & 0.638
\end{tabular}

\begin{tabular}{ll}
\multicolumn{3}{c}{ Slow-Target-CUS-Rate } \\
\hline T09 & 0.480 \\
T30 & 0.347 \\
T60 & 0.158 \\
T90 & 0.182 \\
T120 & $\downarrow$
\end{tabular}

Slow-Target-CUS-Amplitude

\begin{tabular}{lll}
\hline T0 & & 0.286 \\
T30 & $\uparrow$ & $0.019^{\star}$ \\
T60 & $\uparrow$ & $0.047^{\star}$ \\
T90 & & 0.066 \\
T120 & & 0.944
\end{tabular}

Slow-Target-CUS-Amplitude

\begin{tabular}{|c|c|c|}
\hline T0 & & 0.636 \\
\hline T30 & & 0.093 \\
\hline T60 & $\uparrow$ & $0.018^{\star}$ \\
\hline T90 & & 0.173 \\
\hline T120 & & 0.919 \\
\hline
\end{tabular}

Fast-Target-Gain

\begin{tabular}{|c|c|c|}
\hline T0 & & 0.285 \\
\hline T30 & $\downarrow$ & $0.012^{\star}$ \\
\hline T60 & & 0.114 \\
\hline T90 & & 0.333 \\
\hline T120 & & 0.953 \\
\hline
\end{tabular}

Fast-Target-Gain

\begin{tabular}{ll}
\hline T0 & 0.879 \\
T30 & 0.314 \\
T60 & 0.879 \\
T90 & 0.139 \\
T120 & 0.169
\end{tabular}

Fast-Target-CUS-Rate

\begin{tabular}{lll}
\hline T0 & & 0.575 \\
T30 & $0.047^{\star}$ \\
T60 & $\uparrow$ & 0.241 \\
T90 & & 0.333 \\
T120 & & 0.678
\end{tabular}

Fast-Target-CUS-Rate

\begin{tabular}{|c|c|c|}
\hline T0 & & 0.721 \\
\hline T30 & & 0.508 \\
\hline T60 & & 0.508 \\
\hline T90 & & 0.093 \\
\hline T120 & $\uparrow$ & 0.013 \\
\hline
\end{tabular}

Fast-Target-CUS-Amplitude

\begin{tabular}{|c|c|c|c|c|c|}
\hline T0 & & 0.476 & T0 & & 0.767 \\
\hline T30 & $\uparrow$ & $0.013^{*}$ & T30 & $\uparrow$ & $0.015^{\star}$ \\
\hline T60 & & 0.735 & T60 & & 0.919 \\
\hline T90 & & 0.889 & T90 & & 0.333 \\
\hline T120 & & 0.678 & T120 & & 0.386 \\
\hline
\end{tabular}

${ }^{*} p<.05$.

or CUS amplitude (apomorphine at $5 \% / \mathrm{sec}$ ). This is the frst report of the effects of these agents on smooth pursuit gain and CUS.

The placebo effects were presumably caused by the passage of time and repeated testing, rather than any effect of placebo per se. The gradual decline in slowtarget-gain and increase in slow-target-CUS-rate after placebo probably reflects the cumulative effects of fa- tigue. This is supported by the finding that subjects were significantly sleepier at T120 than at T0 after placebo. Although fatigue is frequently cited as a potential cause of low gain (Leigh and Zee 1991), we are not aware of any previous study that clearly documented this effect. The decline in slow-target-gain was mild in magnitude (from 0.912 to 0.859 over $120 \mathrm{~min}$ ). It is noteworthy, furthermore, that no decline was observed 
Table 3. Significance $(p)$ Values for Tests of the Effects of Placebo, Apomorphine, or MK-212 on Subjective Ratings of Side-Effects: Wilcoxon Signed-ranks Test

\begin{tabular}{lccc}
\hline \multicolumn{1}{c}{ Side-Effect } & $\begin{array}{c}\text { Placebo } \\
\text { T120 } \\
\boldsymbol{p} \text {-Value }\end{array}$ & $\begin{array}{c}\text { Apomorphine } \\
\text { T30 } \\
\boldsymbol{p} \text {-Value }\end{array}$ & $\begin{array}{c}\text { MK-212 } \\
\text { T120 } \\
\boldsymbol{p} \text {-Value }\end{array}$ \\
\hline Sleepiness & 0.012 & 0.018 & 0.068 \\
Nausea & 1.0 & 0.128 & 0.109 \\
Dizziness & 1.0 & 0.106 & 0.361 \\
Restlessness & 0.178 & 0.201 & 0.138 \\
Strange feeling & 1.0 & 0.465 & 0.361 \\
Irritability & 1.0 & 0.715 & 0.423 \\
\hline
\end{tabular}

for fast-target-gain. If one accepts the hypothesis that the decline in slow-target-gain is caused by fatigue, the absence of an effect for the fast target suggests that fatigue is less of a factor in tracking a substantially faster target. Other evidence, described below, is consistent with the hypothesis that performance when tracking a fast target is less susceptible to side-effects than when tracking a slow target. The susceptibility of slow-target performance to fatigue may simply reflect that this target is presented for a substantially longer period of time ( $82 \mathrm{sec})$ than the fast target $(32.5 \mathrm{sec})$, because the same number of ramps are presented at both speeds. Perhaps the slow target would, therefore, demand greater sustained vigilance than the fast target.

Apomorphine led to a reduction in slow-target-gain and fast-target-gain $30 \mathrm{~min}$ postinjection. The reduction was marked and rapid (from .895 to 0.771 in $30 \mathrm{~min}$ for slow-target-gain and from 0.844 to 0.751 for fasttarget-gain). As mentioned previously, the pharmacokinetic data, as well as studies of motor effects in Parkinson patients, indicate that apomorphine can act within 10 min (Gancher et al. 1989; Truelle et al. 1975). Further study is required to determine if the peak effect of apomorphine on gain occurs before $30 \mathrm{~min}$. The de- cline in slow-target-gain was associated with a signifcant increase in corrective CUS amplitude, and there were trends toward increasing CUS rate at both target speeds.

Apomorphine also caused a statistically significant increase in sleepiness at T30, an effect that is well documented (Meltzer 1982). Furthermore, the effect of apomorphine on slow-target-gain was significantly correlated $\left(r_{s}=-.84\right)$ with the effect on sleepiness. This pattern of results raises the possibility that the reduction in slow-target-gain after apomorphine was secondary to sedation. A number of compounds with sedating effects have been found to reduce smooth pursuit gain, including barbiturates (Padoan et al. 1992), benzodiazepines (Rothenberg and Selkoe 1981; Bittencourt et al. 1983; Padoan et al. 1992), alcohol (Baloh et al. 1979; Barnes et al. 1984; Tedeschi et al. 1984; Stapleton et al. 1986), nitrous oxide (Magnusson et al. 1989), and methadone (Rothenberg et al. 1980). However, in an acute study of the effects of chlorpromazine on eye movements, Holzman et al. (1975) found no effect on eyetracking in the presence of a large soporific effect. In the present study, the effect of apomorphine on fasttarget-gain was not related to increases in sleepiness $\left(r_{s}=-.26\right)$, even though the two gain effects were comparable in magnitude. It is possible that the reduced correlation between increased sleepiness and decreased gain during the fast target resulted from less statistical power (two fewer subjects), or a restriction of the range of gain changes. However, the magnitude of the correlation was much less, suggesting that many more subjects ( 89 subjects, assuming power $=0.8$ and 1-tailed alpha $<0.05$ ) would be required to find a significant relationship (Cohen 1988). Also, the standard deviation of slow-target-gain change (0.078) was actually less than that of fast-target-gain change (0.083), indicating the absence of a "range restriction" limitation. Thus, the present evidence suggests that the effect of apomor-

Table 4. Relationship between Change in Gain and Change in Side-Effects at the Time of Peak Gain Effect

\begin{tabular}{|c|c|c|c|c|c|c|c|c|}
\hline \multirow{2}{*}{$\begin{array}{l}\text { Maximum } \\
\text { Change in }\end{array}$} & \multirow[b]{2}{*}{ After } & & \multicolumn{6}{|c|}{ Spearman Correlation Coefficients } \\
\hline & & & Sleepiness & Nausea & Dizziness & Restlessness & Strangeness & Irritability \\
\hline Slow-target-gain & Placebo & $\begin{array}{c}r \\
p \text {-Value }\end{array}$ & $\begin{array}{l}0.04 \\
0.92\end{array}$ & $\begin{array}{l}\text { NA } \\
\text { NA }\end{array}$ & $\begin{array}{l}0.27 \\
0.48\end{array}$ & $\begin{array}{r}-0.08 \\
0.84\end{array}$ & $\begin{array}{l}\text { NA } \\
\text { NA }\end{array}$ & $\begin{array}{l}0.18 \\
0.64\end{array}$ \\
\hline Slow-target-gain & Apomorphine & $\stackrel{r}{p \text {-Value }}$ & $\begin{array}{r}-0.84 \\
0.01\end{array}$ & $\begin{array}{r}-0.36 \\
0.34\end{array}$ & $\begin{array}{r}-0.86 \\
0.00\end{array}$ & $\begin{array}{r}-0.52 \\
0.15\end{array}$ & $\begin{array}{r}-0.37 \\
0.33\end{array}$ & $\begin{array}{r}-0.76 \\
0.02\end{array}$ \\
\hline Fast-target-gain & Apomorphine & $\stackrel{r}{p \text {-Value }}$ & $\begin{array}{r}-0.26 \\
0.50\end{array}$ & $\begin{array}{r}-0.33 \\
0.38\end{array}$ & $\begin{array}{r}-0.13 \\
0.74\end{array}$ & $\begin{array}{l}0.32 \\
0.40\end{array}$ & $\begin{array}{r}-0.27 \\
0.48\end{array}$ & $\begin{array}{r}-0.45 \\
0.23\end{array}$ \\
\hline Slow-target-gain & MK-212 & $\stackrel{r}{p \text {-Value }}$ & $\begin{array}{r}-0.37 \\
0.33\end{array}$ & $\begin{array}{r}-0.05 \\
0.91\end{array}$ & $\begin{array}{r}-0.20 \\
0.61\end{array}$ & $\begin{array}{r}-0.44 \\
0.24\end{array}$ & $\begin{array}{r}-0.24 \\
0.54\end{array}$ & $\begin{array}{l}0.18 \\
0.64\end{array}$ \\
\hline Fast-target-gain & MK-212 & $\stackrel{r}{p \text {-Value }}$ & $\begin{array}{r}-0.09 \\
0.83\end{array}$ & $\begin{array}{r}-0.07 \\
0.85\end{array}$ & $\begin{array}{r}-0.46 \\
0.22\end{array}$ & $\begin{array}{r}-0.18 \\
0.64\end{array}$ & $\begin{array}{r}-0.63 \\
0.07\end{array}$ & $\begin{array}{r}-0.37 \\
0.33\end{array}$ \\
\hline
\end{tabular}

$\mathrm{NA}=\mathrm{A}$ correlation coefficient could not be computed in the absence of variation. 
phine on fast-target-gain was not strongly related to the sedative effects of apomorphine. One explanation for this pattern of results is that the effect of apomorphine on gain is not secondary to sedation at either target speed. In further support of this notion, MK-212 also tended to increase sleepiness $(p=.068)$, but it was associated with an increase in gain. Nonetheless, the sedative effect of apomorphine may well have contributed to the decline in slow-target-gain, especially if performance when tracking the slow target is more susceptible to sedation, as suggested previously. Future studies employing levodopa for DA stimulation should help to clarify the role of sedation, because levodopa is associated with arousal (Bowen et al. 1975; Sassin 1975; Boivin and Montplasir 1991).

If the effect of apomorphine is due to DA stimulation at some point in the neural pathway controlling smooth pursuit, it would be of great interest to determine where this effect is mediated. The presence of several types of DA receptors, including autoreceptors and postsynaptic receptors, complicates the interpretation. In the present study, we employed a standard "subemetic," "nonsedating" dose of apomorphine $(0.01 \mathrm{mg} /$ $\mathrm{kg}$, or approximately $0.75 \mathrm{mg} /$ person). Although this dose is frequently referred to as an "autoreceptor dose," the evidence supporting this classification is scarce. Several dose-response studies in animals have documented biphasic effects of apomorphine, and thus provide dosages for presynaptic and postsynaptic effects (Ljungberg and Ungerstedt 1976; Protais et al. 1983; Stahle 1992). However, we are aware of only one dose response study in humans that addressed this issue: Lal et al. (1989) recently reported that doses from 0.0035 to $0.005 \mathrm{mg} / \mathrm{kg}$ antagonized yawning, whereas doses above 0.007 stimulated yawning. Lal et al. (1989) concluded that doses above $0.007 \mathrm{mg} / \mathrm{kg}$ stimulate postsynaptic receptors. This is consistent with the finding that doses at or above $0.01 \mathrm{mg} / \mathrm{kg}$ reduce motor symptoms in Parkinson's disease (Duby et al. 1972; Blin et al. 1990) - an effect that is presumably postsynaptic. On the other hand, evidence for a presynaptic effect was provided by Levy et al. (1984), who reported a decrease in CSF levels of the DA metabolite homovanillic acid (HVA) in patients with schizophrenia, after a 0.75 $\mathrm{mg} /$ person dose. Considering that only one study has documented a biphasic response in humans (Lal et al. 1989) and that reported results are not completely consistent, caution precludes a firm conclusion regarding autoreceptor versus postsynaptic receptor stimulation of the dose at this time.

Several studies have evaluated the role of catecholamines in smooth pursuit. Amphetamine increases synaptic DA and norepinephrine (NE) by promoting release and blocking reuptake (Cooper et al. 1991). Most studies have not found an effect of amphetamine on smooth pursuit in normal controls (Tedeschi et al. 1983) or psychiatric patients (Siever et al. 1987; Bylsma and Pivik 1989), although none of these studies measured gain or corrective saccades. Filip et al. (1978) noted an improvement in smooth pursuit after amphetamine in normal volunteers, although the data analysis was idiosyncratic. Ando et al. (1986) found that amphetamine disrupted eye-tracking in a dose-related manner in three monkeys; thus, no clear effect of amphetamine on eyetracking has been established. Furthermore, Tychsen and Sitaram (1989) reported no effect on smooth pursuit gain in normal controls after alpha-methylparatyrosine, which blocks the synthesis of DA and NE. Also, Siever et al. (1986) found no correlation between CSF levels of the DA metabolites HVA or dihydroxyphenylacetic acid and smooth pursuit. As previously mentioned, chronic neuroleptic treatment does not appear to affect smooth pursuit. These results do not consistently implicate DA in smooth pursuit; however, these studies generally employed nonspecific smooth pursuit measures and indirect manipulations or measures of the DA system.

Several studies have reported low gain in Parkinson's disease (White et al. 1983; Gibson et al. 1987), which is associated with degeneration of the nigrostriatal DA system and marked DA depletion. In one report, clinical improvement with chronic treatment of dopaminergic drugs was associated with an increase in gain (Gibson et al. 1987), although Sharpe et al. (1987) did not find an increase in gain after levodopa treatment in Parkinson's disease patients. This clinical evidence suggests that low DA in the striatum is associated with low gain and is consistent with an apomorphineinduced stimulation of DA autoreceptors on the nigrostriatal DA neurons in the present study; however, neurophysiological experiments have not implicated the nigrostriatal DA system in smooth pursuit function (Sharpe et al. 1989).

Thus, the extant literature does not provide strong support for or against a direct role of the DA system in the control of smooth pursuit; however, the evidence for a role of DA from the present study is based upon the application of a direct-acting agent and state-of-theart smooth pursuit assessment, accompanied by assessment of subjective side-effects. Clarification of the role of DA in smooth pursuit thus deserves further investigation. Studies in normal subjects using specific, directacting agents, and state-of-the-art assessments are likely to provide the most interpretable evidence.

In contrast to the reduction in gain after apomorphine, MK-212 was followed by an elevation of slowtarget-gain and fast-target-gain. The effect was delayed compared to the apomorphine effect probably as a result of the difference in the route of administration (PO versus $\mathrm{SC}$ ). There were also statistically significant monotonic decreases in CUS rate for both target speeds after MK-212. Indeed, the strongest effect of MK-212 
on eye movements was the monotonic decrease in fasttarget-CUS-rate $(p<.001)$. The finding that MK-212 can improve smooth pursuit performance in normal subjects is surprising, especially because we are not aware of any other agent that has this effect. The increases in gain were not large ( 0.897 to 0.936 for slow-targetgain, and 0.814 to 0.88 for fast-target-gain); however, the statistical analysis employed was conservative, and accounted for multiple, non-independent posthoc comparisons.

The increase in gain after MK-212 was probably unrelated to side-effects. First, there is no obvious a priori connection between improved smooth pursuit performance and side-effects. Also, there was no significant effect of MK-212 on side-effects, although there was a trend toward increased sleepiness. Moreover, at the time of peak effect of MK-212 (T120), there were no statistically significant correlations between changes in side-effects and changes in gain. One correlation approached statistical significance, namely change in feelings of strangeness $\left(r_{s}=-0.63, p=.067\right)$. It is unlikely that the effect of MK-212 on gain was mediated by feelings of strangeness, however. Perhaps those subjects who felt most strange after MK-212 were more sensitive to the central 5-HT stimulatory effect of this agent, and thus were more sensitive to effects on smooth pursuit gain.

To our knowledge, only one study has evaluated the effect of a 5-HT specific agent on smooth pursuit gain. Stott et al. (1989) studied the effect of ondansetron, a 5- $\mathrm{HT}_{3}$ antagonist, on smooth pursuit in normal volunteers and found a small, but statistically significant reduction in gain; however, this effect of ondansetron may be related to effects on the DA system, because $5-\mathrm{HT}_{3}$ antagonists have been shown to be extremely potent in antagonizing the behavioral consequences of increased mesolimbic DA activity (Costall et al. 1990). This notion assumes that increased mesolimbic DA is associated with increased gain. This would only follow if the gain reduction after apomorphine was mediated by DA autoreceptors, that similarly decrease DA release. The gain-elevating effect of MK-212 may also be related to effects on $5-\mathrm{HT}_{3}$ receptors, because MK-212 also interacts with these receptors(Glennon et al. 1989); however, it is premature to speculate which type of $5-\mathrm{HT}$ receptor is stimulated by MK-212. Specific antagonists of $5-\mathrm{HT}_{1 \mathrm{~A}}, 5-\mathrm{HT}_{2 \mathrm{~A}}, 5-\mathrm{HT}_{2 \mathrm{C}}$, or even $5-\mathrm{HT}_{3}$ receptors will be needed for clarification.

The effects of 5-HT on the optokinetic slow phase response (that is similar to smooth pursuit) have been studied elegantly in the crab, Leptograpsus variegatus, by Erber and Sandeman (1989). They found that systemic and ocular injections of 5-HT increased optokinetic slow phase amplitude - a finding that is analogous to an increase in smooth pursuit gain.

It is of particular interest that the effects of apomor- phine and MK-212 on slow-target-gain were inversely correlated. It is well established that serotonin can exert an inhibitory effect on the dopaminergic system (Korsgaard et al. 1985; Nash and Meltzer 1991). As a specific relevant example, MK-212 has been shown to block apomorphine induced hypothermia (Menon and Vivonia 1981); thus, the ability of MK-212 to increase gain may be due to inhibition of a tonic inhibitory effect of DA neurons on gain. The fact that there was a significant correlation despite the obvious contributions of pharmacokinetic variability in absorption, metabolism, and receptor dynamics of these agents, suggests that dopaminergic and serotoninergic mechanisms regulating gain are interconnected, either directly, or via an intermediary.

If confirmed, the present results could lead to the development of a new method to study central serotoninergic and dopaminergic mechanisms in man. Smooth pursuit performance may provide a nonhypothalamically mediated, behaviorally-based measure for acute challenge studies. The effect of apomorphine and/or MK-212, as well as specific $\mathrm{D}_{1}, \mathrm{D}_{2}, 5-\mathrm{HT}_{1 \mathrm{~A}}, 5-\mathrm{HT}_{2 \mathrm{~A}}$, and $5-\mathrm{HT}_{2} \mathrm{C}$ agonists on smooth pursuit could provide important new clues regarding receptor sensitivity in clinical populations, and on the effect of psychotropic drug treatment.

\section{ACKNOWLEDGMENT}

This research was supported by USPHS grants MH-47574 (to Dr. Friedman), MH-41684 (to Dr. Meltzer) and GCRC MO1RR00080, by the Department of Veterans Affairs and grants to Dr. Meltzer from the Elisabeth Severance Prentiss, John Pascal Sawyer and Laureate Foundations. HYM is the recipient of a USPHS Research Career Scientist Award (MH 47808).

\section{REFERENCES}

Abel LA, Hertle RW (1988): Effects of psychoactive drugs on ocular motor behavior. In Johnston CW, Pirozollo FJ (eds), Neuropsychology of Eye Movements. Hillsdale, New Jersey, Lawrence Erlbaum Associates, pp 81-114

Abel LA, Levin S, Holzman PS (1992): Abnormalities of smooth pursuit and saccadic control in schizophrenia and affective disorders. Vision Res 32:1009-1014

Ando K, Johanson CE, Schuster CR (1986): Effects of dopaminergic agents on eye tracking before and after repeated methamphetamine. Pharmacol Biochem Behav 24:693-699

Baloh RW, Sharma S, Moskowitz H, Griffith R (1979): Effect of alcohol and marijuana on eye movements. Aviat Space Environ Med 50(1):18-23

Barnes GR (1984): The effects of ethyl alcohol on visual pursuit and suppression of the vestibulo ocular reflex. Acta Otolaryngol Suppl Stockh 406:161-166

Bittencourt PR, Wade P, Smith AT, Richens A (1983): Ben- 
zodiazepines impair smooth pursuit eye movements. $\mathrm{Br}$ J Clin Pharmacol 15(2):259-262

Blin O, Durup M, Paihous J, Serratrice G (1990): Akathesia, motility, and locomotion in healthy volunteers. Clin Neuropharmacol 13:426-435

Boivin DB, Montplasir J (1991): The effects of L-dopa on excessive daytime sleepiness in narcolepsy. Neurology 41:1267-1269

Bowen FP, Kamienny RS, Burns MM, Yahr MD (1975): Parkinsonism: Effects of levodopa treatment on concept formation. Neurology 25:701-704

Bylsma FW, Pivik RT (1989): The effects of background illumination and stimulant medication on smooth pursuit eye movements of hyperactive children. J Abnorm Child Psychol 17:73-90

Choudhary MS, Craigo S, Roth BL (1993): A single point mutation (Phe ${ }^{340 \rightarrow \text { Leu }^{340}}$ ) of a conserved phenylalanine abolishes 4-[ $\left.{ }^{125} \mathrm{I}\right]$ Iodo-(2,5-dimethoxy)phenylisopropylamine and $\left[{ }^{3} \mathrm{H}\right]$ mesulergine, but not $\left[{ }^{3} \mathrm{H}\right]$ Ketanserin binding to 5 -hydroxytryptamine 2 receptors. Mol Pharmacol 43:755-761

Clementz BA, Sweeney JA (1990): Is eye movement dysfunction a biological marker for schizophrenia: A methodological review. Psychol Bull 108:77-92

Clineschmidt, BV (1979): MK-212: A serotonin-like agonist in the CNS. Gen Pharmacol 10:287-290

Clineschmidt BV, Hanson HM, Pflueger AB, McGriffin JC (1977): Anorexigenic and ancillary actions of MK-212 (6-chloro-2-[1-piperazinyl]pyrazine). Psychopharmacology 55:27-33

Clineschmidt BV, Reiss DR, Pettibone DJ, Robinson JL (1985): Characterization of 5-hydroxytryptamine receptors in the rat stomach fundus. J Pharmacol Exp Ther 235:696-708

Cohen J (1988): Statistical Power Analyses for the Behavioral Sciences. New York, Lawrence Erlbaum Associates, Inc

Cooper JR, Bloom FE, Roth RH (1991): The biochemical basis of neuropharmacology, ed 6, New York, Oxford University

Costall B, Naylor RJ, Tyers MB (1990): The psychopharmacology of 5- $\mathrm{HT}_{3}$ receptors. Pharmac Ther 47:181-202

Davis KL, Kahn RS, Ko G, Davidson M (1991): Dopamine in schizophrenia: A review and reconceptualization. Am J Psychiatry 148:1474-1486

Düby SE, Cotzias GC, Papavasiliou PS, Lawrence WH (1972): Injected apomorphine and orally administered levodopa in parkinsonism. Arch Neurol 27:474-480

Erber J, Sandeman DC (1989): The effect of serotonin and octopamine on the optokinetic response of the crab, Leptograpsus variegatus. J Neurobiol 20:667-680

Filip V, David I, Filipova M (1978): Single-dose effects of amphetamine on smooth pursuit eye movements in man. Activ Nerv Sup 20:293-295

Friedman L, Jesberger JA, and Meltzer HY (1991): A model of smooth pursuit performance illustrates the relationship between gain, catch-up saccade rate and catch-up saccade amplitude in normal controls and patients with schizophrenia. Biol Psychiatry 30:537-556

Friedman L, Abel LA, Jesberger JA, Malki A, Meltzer HY (1992a): Saccadic intrusions into smooth pursuit in pa- tients with schizophrenia or affective disorder, and normal controls. Biol Psychiatry 31:1110-1118

Friedman L, Able LA, Jesberger JA, Malki A, Brar R, Meltzer HY (1992b): A methodology for the assessment of smooth pursuit dysfunction in psychiatric patients and normal controls. Int J Methods Psychiatry Res 2:209-216

Gancher ST, Woodward WR, Boucher B, Nutt JG (1989): Peripheral pharmacokinetics of apomorphine in humans. Ann Neurol 26:232-238

Gibson JM, Pimlott R, Kennard C (1987): Ocular motor and manual tracking in Parkinson's disease and the effect of treatment. J Neurol Neurosurg Psychiatry 50:853-860

Glennon RA, Ismaiel AEM, McCarthy BG, Peroutka SJ (1989): Binding of arylpiperizines to $5-\mathrm{HT}_{3}$ serotonin receptors: Results of a structure-affinity study. Eur J Pharmocol 1658:387-392

Goldstein M, Lieberman AN, Takasugi N, Shimizu Y, Kuga $S$ (1990): The antiparkinsonian activity of dopamine agonists and their interaction with central dopamine receptor subtypes. Adv Neurol 53:101-106

Hoddes E, Zarcone V, Smythe H, Phillips R, Dement WC (1973): Quantification of sleepiness: A new approach. Psychophysiology 10:431-436

Holzman PS, Levy DL, Uhlenhuth EH, Procter LR, Freedman DX (1975): Smooth-pursuit eye movements, and diazepam, CPZ, and secobarbital. Psychopharmacologia (Berl) 44:111-115.

Hoyer D (1988): Functional correlates of serotonin $5-\mathrm{HT}_{1 \mathrm{C}}$ recognition sites. J Receptor Res 8:59-81

King BH, Brazell C, Dourish CT, Middlemiss DN (1989): MK212 increases rat plasma ACTH concentration by activation of the $5-\mathrm{HT}_{1} \mathrm{C}$ receptor subtype. Neurosci Lett 105: 174-176

Korsgaard S, Gerlach J, Christensson E (1985): Behavioral aspects of serotonin-dopamine interaction in the monkey. Eur J Pharmacol 118:245-252

Lal S, Tsfay Y, Thavundayil JX, Thompson TR, Kiely ME, Nair NP, Grassino A, Dubrovsky B (1989): Apomorphine: clinical studies on erectile impotence and yawning. Biol Psychiatry 13:329-39

Lee HS, Bastani B, Friedman L, Ramierz L, Meltzer HY (1992): Effect of the serotonin agonist, MK-212, on body temperature in schizophrenia. Biol Psychiatry 31:460-470

Leigh RJ, Zee DS (1991): The Neurology of Eye Movements, Ed 2. Philadelphia, FA Davis Co

Levin S, Luebke A, Zee DS, Hain RC, Robinson DA, Holzman PS (1988): Smooth pursuit eye movements in schizophrenics: Quantitative measurements with the search-coil technique. J Psychiatr Res 22:195-206

Levy MI, Dais BM, Mohs RC, Kendler KS, Mathé AA, Trigos G, Horvath TB, Davis KL (1984): Apomorphine and schizophrenia. Arch Gen Psychiatry 41:520-524

Levy DL, Lipton RB, Holzman PS, Davis JM (1983): Eye tracking dysfunction unrelated to clinical state and treatment with haloperidol. Biol Psychiatry 18:813-819

Levy DL, Holzman PS, Matthysse S, Mendell NR (1993): Eye tracking dysfunction and schizophrenia: A critical perspective. Schizophr Bull 19:461-536

Lipton RB, Levy DL, Holzman PS, Levin S (1983): Eyemove- 
ment dysfunctions in psychiatric patients: A review. Schizophr Bull 9:13-32

Ljungberg T, Ungerstedt U (1976): Automatic registration of behavior related to dopamine and noradrenaline transmission. Eur J Pharmacol 36:181-188

Lowy MT, Meltzer HY (1988): Stimulation of serum cortisol and prolactin secretion in humans by MK-212, a centrally active serotonin agonist. Biol Psychiatry 23:818-828

Magnusson M, Padoan S, Ornhagen H (1989): Evaluation of smooth pursuit and voluntary saccades in nitrous oxide induced narcosis. Aviat Space Environ Med 60:977-982

Mansbach RS, Barrett JE (1986): Effects of MK-212 (6-chloro2-[1-piperazinyl]pyrazine) on schedule-controlled behavior and their reversal by 5-HT antagonists in the pigeon. Neuropharmacology 25:13-19

Meltzer HY (1982): Dopamine autoreceptor stimulation: Clinical signifıcance. Pharmacol Biochem Behav 17 (Suppl 1):1-10

Meltzer HY (1989): Clinical studies on the mechanism of action of clozapine: The dopamine-serotonin hypothesis of schizophrenia. Psychopharmacology 99 (Suppl) S18S27

Meltzer HY, Stahl SM (1976): The dopamine hypothesis of schizophrenia: A review. Schizophr Bull 2:19-76

Menon MK, Vivonia CA (1981): Modification of apomorphine hypothermia by drugs affecting brain 5-hydroxytryptamine function. Eur J Pharmacol 76:223-227

Nash JF, Meltzer HY (1991): Chapter 4: Neuroendocrine studies in psychiatric disorders: The role of serotonin. In The role of serotonin in psychiatric disorders, Brown SL, and van Praag HM (eds), New York, Brunner-Mazel pp 57-90

Norusis MJ (1988): SPSS/PC + V2.0 Base Manual. Chicago: SPSS Inc.

Padoan S, Korttila K, Magnusson M, Pyykko I, Schalen L (1992): Effect of intravenous diazepam and thiopental on voluntary saccades and pursuit eye movements. Acta Otolaryngol Stockh 112(4):579-588

Protais P, Dubuc I, Constentin J (1983): Pharmacological characteristics of dopamine receptors involved in the dual effect of dopamine agonists on yawning behavior in rats. Eur J Pharmacol 94:271-280

Roth BL, Ciaranello RD, Meltzer HY (1992): Binding of typical and atypical antipsychotic agents to transiently expressed 5-HT $1 \mathrm{C}$ receptors. J. Pharm Exp Ther 260:13611365

Rothenberg S, Schottenfeld S, Selkoe D, Gross K (1980): Specific oculomotor deficit after acute methadone. II. Smooth pursuit eye movements. Psychopharmacology Berl 67(3):229-234

Rothenberg SJ, Selkoe D (1981): Specifıc oculomotor deficit after diazepam. II. Smooth pursuit eye movements. Psychopharmacology Berl 74(3):237-240

Sassin JF (1975): Drug-induced dyskinesia in monkeys. In Meldrum BS and Marsden CD (eds), Advances in Neurology, Vol 10. New York, Raven Press, pp 47-54

Schechter MD, Greer NL (1987): Evidence that the stimulus properties of apomorphine are mediated by both $\mathrm{D}_{1}$ and $\mathrm{D}_{2}$ receptor activation. Life Sci 40:2461-2471
Sharpe JA, Fletcher WA, Lang AE, Zackon DH (1987): Smooth pursuit during dose-related on-off fluctuations in Parkinson's disease. Neurology 37:1389-1392

Sharpe JA, Morrow MJ, Johnston JL (1989): Smooth pursuit: Anatomy, physiology, and disorders. Bull Soc Belge Ophthalmol 237:113-144

Siegel S, Castellan NJ, Jr (1988): Nonparametric Statistics for the Social Sciences, ed 2, New York, McGraw Hill

Siever LJ, Insel TR, Hamilton J, Nurnberger J, Alterman I, Murphy DL (1987): Eye-tracking, attention, and amphetamine challenge. J Psychiatr Res 21(2):129-135

Siever LJ, van Kammen DP, Linnoila M, Alterman I, Hare T, Murphy DL (1986): Smooth pursuit eye movement disorder and its psychobiologic correlates in unmedicated schizophrenics. Biol Psychiatry 21:1167-1174

Spohn HE, Coyne L, Spray J (1988): The effects of neuroleptics and tardive dyskinesia on smooth pursuit eye movement in chronic schizophrenics. Arch Gen Psychiatry 45:833-840

Ståhle L (1992): Do autoreceptors mediate dopamine agonistinduced yawning and suppression of exploration? A critical review. Psychopharmacology 106:1-13

Stapleton JM, Guthrie S, Linnoila M (1986): Effects of alcohol and other psychotropic drugs on eye movements: Relevance to traffic safety. J Stud Alcohol 47(50):426-432

Stott JRR, Barnes GR, Wright RJ, Ruddock CJS (1989): The effect on motion sickness and oculomotor function of $\mathrm{GR}$ $38032 \mathrm{~F}$, a $5-\mathrm{HT}_{3}$-receptor antagonist with anti-emetic properties. Br J Clin Pharmacol 27:147-157

Tabachnick BG, Fidell LS (1989): Using Multivariate Statistics, ed 2, New York, Harper and Row

Tedeschi G, Bittencourt PRM, Smith AT, Richens A (1983): Effect of amphetamine on saccadic and smooth pursuit eye movements. Psychopharmacology 79:190-192

Tedeschi G, Smith AT, Richens A (1984): Effect of meptazinol and ethanol on human psychomotor performance and mood ratings. Hum Toxicol 3(1):37-43

Truelle JL, Chanalet J, Bastard J, Emile J (1975): Enregistrement polygraphique du tremblement et des phenomenes d'hyptertonie dans la maladie de parkinson: Application a l'action de differentes drogues. Rev Neurol (Paris) 121:29-42

Tychsen L, Sitaram N (1989): Catecholamine depletion produces irrepressible saccadic eye movements in normal humans. Ann Neurol 25:444-449

Usui S, Amidror I (1982): Digital low pass differentiation for biological signal processing. IEEE Trans Biomed Eng 10:686-693

White OB, Saint-Cyr JA, Tomlinson RD, Sharpe JA (1983): Ocular motor deficits in Parkinson's disease. Brain 106: 571-587

Wiesel FA, Farde L, Nordström AL (1990): Central D1- and D2-receptor occupancy during antipsychotic drug treatment. Prog Neuropsychopharmacol Biol Psychiatry 14: 759-767

Yarbrough GG, Singh DK, Pettibone DJ (1984): A comparative electrophysiological and biochemical assessment of serotonin (5-HT) and a novel 5-HT agonist (MK-212) on central serotonergic receptors. Neuropharmacology 23: 1271-1277 